\title{
Hypothermia Protects against Fulminant Hepatitis in Mice by Reducing Reactive Oxygen Species Production
}

\author{
Toshiharu Sakurai $^{a}$ Masatoshi Kudo ${ }^{a}$ Tomohiro Watanabe $^{b}$ Katsuhiko Itoh ${ }^{c}$ \\ Hiroaki Higashitsujic ${ }^{c}$ Tadaaki Arizumia ${ }^{a}$ Tatsuo Inoue $^{a}$ Satoru Hagiwara ${ }^{a}$ \\ Kazuomi Ueshima ${ }^{a}$ Naoshi Nishida $^{a}$ Manabu Fukumoto ${ }^{d}$ Jun Fujitac \\ ${ }^{a}$ Department of Gastroenterology and Hepatology, Kinki University School of Medicine, Osakasayama, ${ }^{b}$ Center for \\ Innovation in Immunoregulative Technology and Therapeutics and ${ }^{\mathrm{C}}$ Department of Clinical Molecular Biology, \\ Graduate School of Medicine, Kyoto University, Kyoto, and d Department of Pathology, Institute of Development, \\ Aging and Cancer, Tohoku University, Sendai, Japan
}

\section{Key Words}

Reactive oxygen species · Fulminant hepatitis .

Hypothermia · Cold-inducible RNA-binding protein .

Cold shock

\begin{abstract}
Objective: Mild hypothermia $\left(32-33^{\circ} \mathrm{C}\right)$ shows protective effects in patients with brain damage and cardiac arrest. Although cold-inducible RNA-binding protein (CIRP) contributes to the protective effects of hypothermia through extracellular signal-regulated kinase activation in fibroblasts, the effects of hypothermia in the liver remain unclear. Methods: We analysed the effects of cold temperature on fulminant hepatitis, a potentially fatal disease, using the D-galactosamine (GalN)/lipopolysaccharide (LPS) and concanavalin (con) A-induced hepatitis models in mice. After GalN/LPS administration and anaesthesia, mice in the hypothermia group were kept at $25^{\circ} \mathrm{C}$ and those in control group were kept at $35^{\circ} \mathrm{C}$. After concanavalin A (con A) administration, the mice in the hypothermia group were placed in a chamber with an ambient temperature of $6^{\circ} \mathrm{C}$
\end{abstract}

\section{KARGER}

(c) 2013 S. Karger AG, Basel

0257-2753/13/0316-0440\$38.00/0

E-Mail karger@karger.com

www.karger.com/ddi for 1.5 h. Results: Hypothermia attenuated liver injury and prolonged survival. Activation of c-Jun $\mathrm{N}$-terminal kinase and Akt, which are involved in reactive oxygen species (ROS) accumulation, was suppressed by low temperature. Hypothermia significantly decreased oxidized protein levels, and treatment with $\mathrm{N}$-acetyl-L-cysteine, an antioxidant, attenuated GaIN/LPS-induced liver injury. In con A-induced hepatitis, CIRP expression was upregulated and Bid expression was downregulated, resulting in decreased apoptosis of hepatocytes in the hypothermia group. Conclusions: These data suggest that hypothermia directly protects hepatocytes from cell death via reduction of ROS production in fulminant hepatitis.

๑) 2013 S. Karger AG, Basel

\section{Introduction}

Mild hypothermia has been reported to protect central neurons from ischemic damage [1-3]. Although clinical application of mild hypothermia $\left(32-35^{\circ} \mathrm{C}\right)$ for patients with brain injury and cardiac arrest has been conducted 

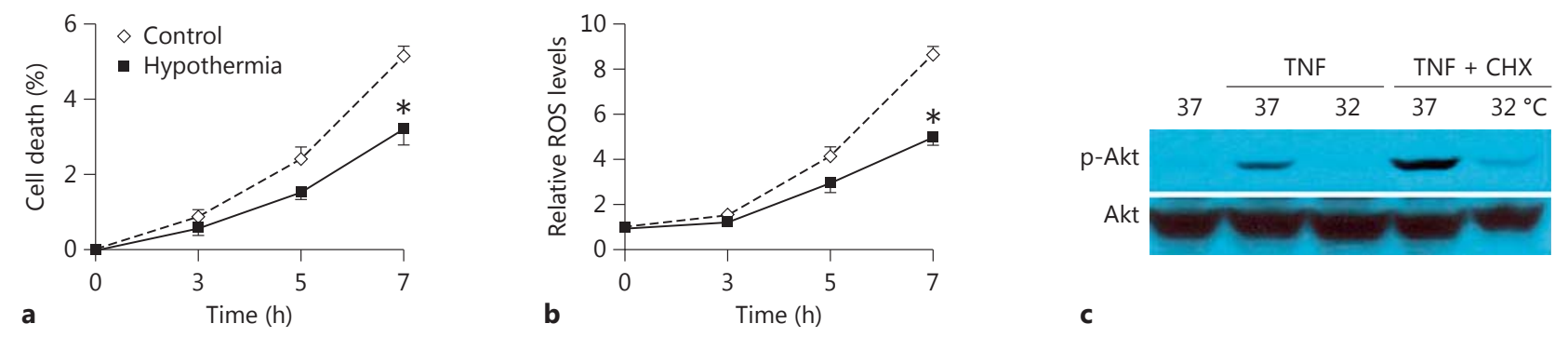

Fig. 1. Low temperature $\left(32^{\circ} \mathrm{C}\right)$ reduced ROS production and cell death in TNF-a-treated cells. HeLa cells were cultured at 37 (control) or $32^{\circ} \mathrm{C}$ (hypothermia) in media containing TNF-a (50 ng/ $\mathrm{ml})$ and/or CHX $(10 \mu \mathrm{g} / \mathrm{ml})$. a, b The cell survival rates and relative ROS levels were examined at the indicated times after initiation of TNF- $\alpha$ treatment. The number of viable cells was estimated by the Trypan blue assay. ROS accumulation was assessed using 5-[and-

with promising results [4], the molecular mechanisms underlying the protective effects of hypothermia are unknown. In endothelial cells kept under hypothermic conditions, significant upregulation of the anti-apoptotic protein Bcl-2 has been reported. Hypothermia decreased the levels of inflammatory chemokines such as IL-8, MCP-1 and COX-2, which could lead to reduced leukocyte recruitment [5]. Low temperature protects mammalian cells from apoptosis initiated by various stimuli in vitro [6]. Cold-inducible RNA-binding protein (CIRP), a protein induced by mild hypothermia, protects against tumour necrosis factor (TNF)- $\alpha$-induced apoptosis via activation of extracellular signal-regulated kinase (ERK) [7].

Fulminant hepatitis, resulting from the acute hepatitis caused by viral infection, alcohol or drugs, is associated with high mortality, and development of a new therapy is necessary. This pathophysiological disturbance is caused by excessive hepatocyte death, in which TNF- $\alpha$ plays an important role [8]. Reactive oxygen species (ROS) are another major mediator of inflammation and reduction of ROS levels leads to attenuation of hepatic injury [9]. Akt activation increases intracellular ROS levels [10]. ROS accumulation inhibits mitogen-activated protein kinase (MAPK) phosphatases, resulting in prolonged c-Jun Nterminal kinase (JNK) activation, which contributes to ROS accumulation and hepatocyte death [11]. Here, we analysed the effects of hypothermia on fulminant hepatitis using murine hepatitis models.

Hypothermia Protects against Fulminant Hepatitis in Mice 6]-chloromethyl-2', $7^{\prime}$-dichlorodihydrofluorescein diacetate (CM$\mathrm{H}_{2} \mathrm{DCFDA}$ ). The values are shown relative to non-treated cells; results are the mean \pm SEM. ${ }^{*} p<0.05$ versus culture at $37^{\circ} \mathrm{C}$ (control). c After treatment with TNF- $\alpha$ or TNF- $\alpha$ plus CHX, cell lysates were prepared and analysed by Western blotting using the indicated antibodies.

\section{Materials and Methods}

\section{Cell Culture}

Human HeLa cells were maintained in Dulbecco's modified Eagle medium supplemented with $10 \%$ foetal bovine serum at 32 or $37^{\circ} \mathrm{C}$ in a humidified atmosphere of $5 \% \mathrm{CO}_{2}$ in air. For induction of cell death, confluent cultures of cells were incubated with TNF- $\alpha(50 \mathrm{ng} / \mathrm{ml})$ in the presence of cycloheximide (CHX; $10 \mu \mathrm{g}$ / $\mathrm{ml}$ ). The number of viable cells was estimated by Trypan blue assay. To assess intracellular ROS levels, TNF- $\alpha$-treated cells were resuspended in PBS containing $10 \mu \mathrm{M}$ 5-[and-6]-chloromethyl$2^{\prime}, 7^{\prime}$-dichlorodihydrofluorescein diacetate $\left(\mathrm{CM}-\mathrm{H}_{2} \mathrm{DCFDA}\right.$; Invitrogen, Carlsbad, Calif., USA), maintained at $37^{\circ} \mathrm{C}$ in the dark for $30 \mathrm{~min}$, and analysed by flow cytometry.

\section{Western Blot Analysis}

Western blot analysis was performed as previously described [12]. The antibodies used were as follows: anti-phospho Akt, antiAkt, anti-phospho-JNK, anti-JNK, anti-phospho-ERK, anti-ERK (Cell Signaling Technology, Danvers, Mass., USA), anti-Bcl-2, anti-Bad, anti-Bid (BD Transduction Laboratory, Lexington, Ky., USA), anti- $\beta$-actin (Sigma, St. Louis, Mo., USA), anti-Bcl-xL and anti-HNF-3 $\gamma$ (Santa Cruz Biotechnology, Santa Cruz, Calif., USA). Rabbit polyclonal antibody recognizing $C$ terminus of mouse CIRP was prepared as described [13]. To quantify ROS accumulation, an OxyBLOT ${ }^{\mathrm{TM}}$ Protein Oxidation Detection Kit (Millipore, Billerica, Mass., USA) was used.

\section{Fulminant Hepatitis Model}

C57BL/6 mice, 4-12 weeks old, were purchased from Japan SLC (Shizuoka, Japan) and were kept at $25^{\circ} \mathrm{C}$ and $55 \%$ relative humidity in a 12-hour day/night cycle with free access to food and water. To induce hepatitis, D-galactosamine (GalN; $1,000 \mathrm{mg} / \mathrm{kg}$, Sigma) and lipopolysaccharide (LPS; 0.1 or $35 \mu \mathrm{g} / \mathrm{kg}$, Sigma) were injected i.p. Thereafter, mice were anesthetized with urethane or 


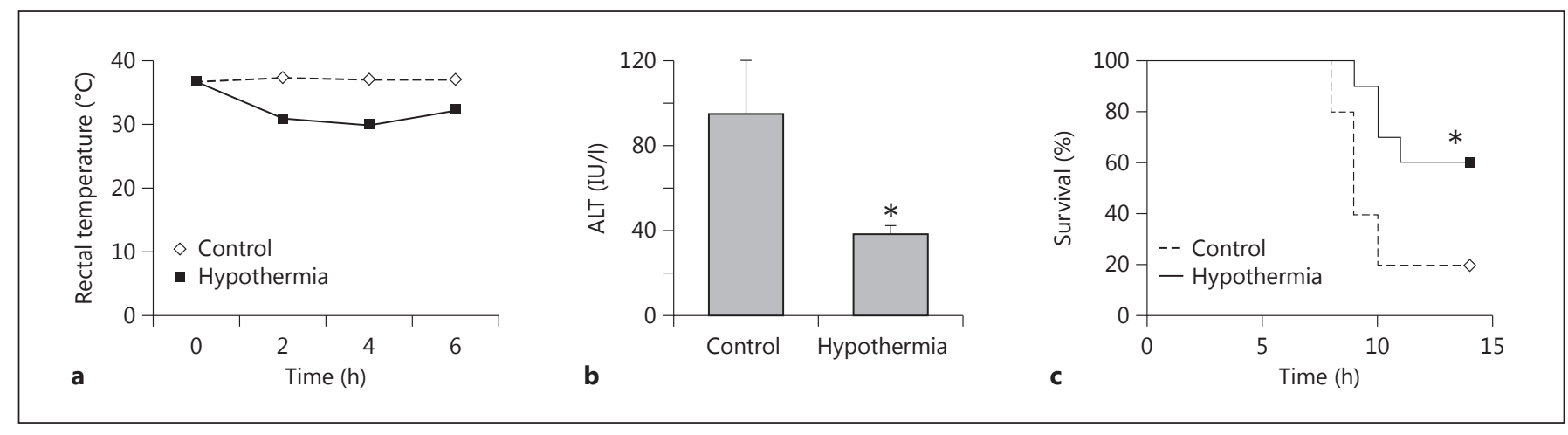

Fig. 2. Hypothermia ameliorates GalN/LPS-induced hepatitis. a Rectal temperatures of mice in the control $(n=10)$ and hypothermia $(n=10)$ groups were monitored after injection of GalN $(1,000 \mathrm{mg} / \mathrm{kg})$ and LPS $(0.1 \mu \mathrm{g} / \mathrm{kg}) ;$ results are the mean. b Mice were injected with GalN $(1,000 \mathrm{mg} / \mathrm{kg})$ and LPS $(0.1 \mu \mathrm{g} / \mathrm{kg})$, and $8 \mathrm{~h}$ after the injection serum ALT levels were examined; results are

pentobarbital and divided into 2 groups: mice placed in a chamber with an ambient temperature of $25^{\circ} \mathrm{C}$ (hypothermia group) and those placed on a plate of $35^{\circ} \mathrm{C}$ (control group). To investigate the protective effects of N-acetyl-L-cysteine (NAC; Sigma), which is an antioxidant, mice were administered with NAC (150 mg/kg, i.p.) $30 \mathrm{~min}$ before GalN/LPS administration (1,000 mg/0.1 $\mu \mathrm{g} / \mathrm{kg}$, i.p.). NAC dissolved in PBS was neutralized before injection. The volume of insensible perspiration was $15 \mathrm{ml} / \mathrm{kg}$ /day and increased by $15 \%$ per $1^{\circ} \mathrm{C}$ upshift of body temperature [14]. The volume of PBS as calculated was injected i.p. into mice in the control group to reduce the effect of dehydration.

Concanavalin A (con A; Sigma) was dissolved in sterile saline and injected into the tail vein at a final volume of $200 \mu \mathrm{l}$. To examine the effect of hypothermia on their survival, the mice were treated with con A at a lethal dose of $35 \mathrm{mg} / \mathrm{kg}$ body weight and divided into 2 groups. One hour after con A injection, the mice in the hypothermia group were placed in a chamber with an ambient temperature of $6^{\circ} \mathrm{C}$ for $1.5 \mathrm{~h}$. Then, all mice were observed at $22^{\circ} \mathrm{C}$. For histological and gene expression analyses, mice were treated with $25 \mathrm{mg} / \mathrm{kg}$ of con A, divided into 2 groups, and euthanised at $24 \mathrm{~h}$ after con A injection.

This work was conducted under the Japanese Law Concerning the Care and Control of Animals and was approved by the Animal Research Committee of the Faculty of Medicine of Kinki and Kyoto University.

\section{Histopathological Examination}

The liver was removed and fixed in 10\% formalin, embedded in paraffin and sliced into $5-\mu \mathrm{m}$ sections for light microscopy. Immunohistochemistry was performed using ImmPRESS ${ }^{\mathrm{TM}}$ reagents (Vector Laboratory, Burlingame, Calif., USA) according to the manufacturer's recommendations. The number of proliferating cells was estimated by staining the sections with a mouse monoclonal anti-proliferating cell nuclear antigen (PCNA) antibody (Cell Signaling Technology). TUNEL staining was performed using tissue sections with an in situ Apoptosis Detection Kit (Takara, Tokyo, Japan). the mean \pm SEM. ${ }^{*} \mathrm{p}<0.05$ versus the control. c After injection with GalN $(1,000 \mathrm{mg} / \mathrm{kg})$ and LPS $(35 \mu \mathrm{g} / \mathrm{kg})$, the survival rates of mice in the control group $(n=10)$ and those in the hypothermia group $(n=10)$ were examined. The difference in the survival rate was analysed by the Kaplan-Meier method and log-rank test. * $\mathrm{p}<$ 0.05 versus the control.

\section{Statistical Analysis}

Data are presented as the mean \pm SEM. Statistical differences between sample means were calculated by analysis of variance, followed by unpaired Student's t test. To compare the survival rates between groups of mice, the log-rank test was used. $\mathrm{p}<0.05$ was considered significant.

\section{Results}

\section{Low Temperature $\left(32^{\circ} \mathrm{C}\right)$ Reduced ROS Production and Cell Death in TNF- $\alpha$-Treated Cells}

Treatment with TNF- $\alpha$ and CHX induced death of $\mathrm{HeLa}$ cells cultured at $37^{\circ} \mathrm{C}$ within $6 \mathrm{~h}$ (fig. 1a). The number of surviving cells was significantly higher when cells were cultured at $32^{\circ} \mathrm{C}$ (hypothermia) than when they were cultured at $37^{\circ} \mathrm{C}$ (control). Similar results were obtained with the human hepatoma cell line $\mathrm{HuH}-7$ [7]. Decreased $\mathrm{H}_{2} \mathrm{O}_{2}$ accumulation in cells cultured at $32^{\circ} \mathrm{C}$ was detected using the ROS indicator 5-[and-6]chloromethyl-2' ${ }^{\prime} 7^{\prime}$-dichlorodihydrofluorescein diacetate (CM- $\mathrm{H}_{2}$ DCFDA; fig. $\left.1 \mathrm{~b}\right)$. Akt activation promotes ROS production [10]. At $60 \mathrm{~min}$ after treatment with TNF- $\alpha$, the protein level of phospho-Akt was lower in HeLa cells cultured at $32^{\circ} \mathrm{C}$ than in cells cultured at $37^{\circ} \mathrm{C}$ (fig. 1c).

\section{Hypothermia Ameliorates GalN/LPS-Induced Hepatitis}

The mean rectal temperature was kept at approximately $30^{\circ} \mathrm{C}$ in the hypothermia group and at $37^{\circ} \mathrm{C}$ in the control group (fig. 2a). As shown in fig. $2 \mathrm{~b}$ and c, hypothermic treatment significantly reduced hepatic injury and improved the survival rate in GalN/LPS-induced hepatitis. 

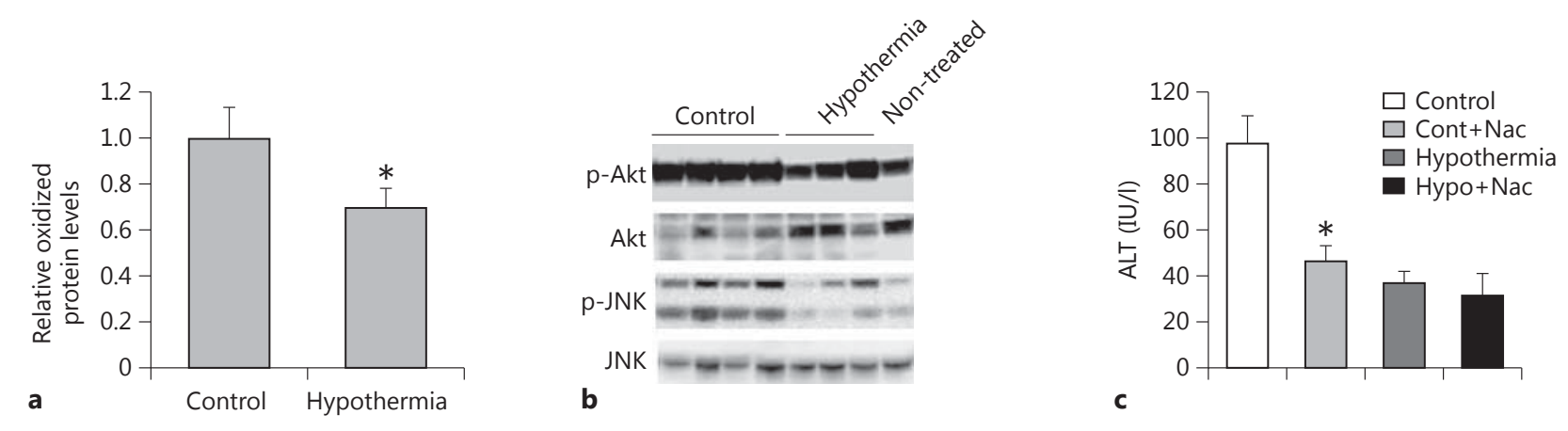

Fig. 3. Hypothermia reduces ROS accumulation in GalN/LPStreated livers. Mice in the control $(\mathrm{n}=8)$ and hypothermia $(\mathrm{n}=8)$ groups were injected with GalN $(1,000 \mathrm{mg} / \mathrm{kg})$ and LPS $(0.1 \mu \mathrm{g} /$ $\mathrm{kg}$ ), and $24 \mathrm{~h}$ after the GalN/LPS injection, tissue lysates were extracted. a ROS accumulation was assessed using the OxyBLOT ${ }^{\mathrm{TM}}$ Protein Oxidation Detection Kit; the results are the mean \pm SEM. $* \mathrm{p}<0.05$ versus the control. b Tissue lysates were analysed by Western blotting using the indicated antibodies. c Mice in the con- trol group $(\mathrm{n}=8)$ and hypothermia group $(\mathrm{n}=8)$ were injected with GalN $(1,000 \mathrm{mg} / \mathrm{kg})$ and LPS $(0.1 \mu \mathrm{g} / \mathrm{kg})$. Mice received NAC $(150 \mathrm{mg} / \mathrm{kg}$, i.p.) in the control group (Cont+Nac; $\mathrm{n}=8)$ and the hypothermia group (Hypo+Nac; $\mathrm{n}=8) 30 \mathrm{~min}$ before GalN/LPS administration $(1,000 \mathrm{mg} / 0.1 \mu \mathrm{g} / \mathrm{kg}$, i.p.). Eight hours after the GalN/LPS injection, the mice were euthanised and serum ALT levels were examined; results are the mean \pm SEM. ${ }^{*} \mathrm{p}<0.05$ versus the control.

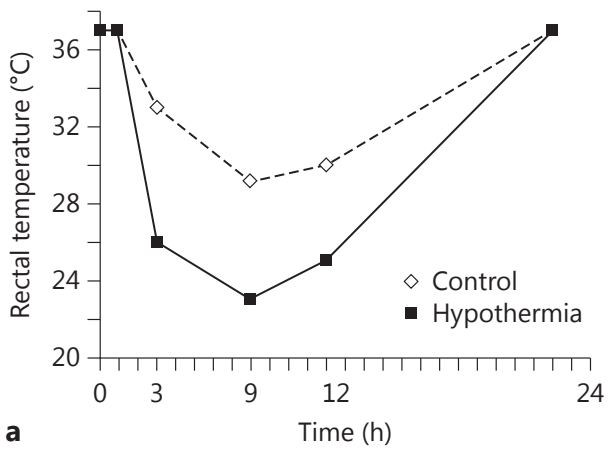

Fig. 4. Hypothermia improves the survival rate in con A-induced hepatitis. a Rectal temperatures of mice in the control $(\mathrm{n}=14)$ and hypothermia $(\mathrm{n}=11)$ groups were monitored after injection of con A $(35 \mathrm{mg} / \mathrm{kg})$; results are the mean. b After injection with con A

\section{Hypothermia Reduces ROS Accumulation in GalN/LPS-Treated Livers}

Mice in the hypothermia group were found to have lower levels of oxidized protein than those in the control group (fig 3a). ROS accumulation inhibits MAPK phosphatases, resulting in prolonged JNK activation, which contributes to hepatocyte death [11]. Accordingly, Akt and JNK activity were decreased in hypo-
$(35 \mathrm{mg} / \mathrm{kg})$, the survival rates of mice in the control group $(\mathrm{n}=14)$ and those in the hypothermia group $(\mathrm{n}=11)$ were examined. The difference in the survival rate was analysed by the Kaplan-Meier method and log-rank test.

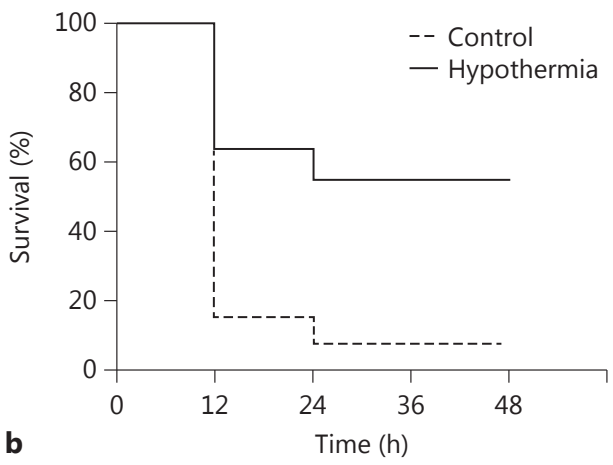
bution of oxidative stress to GalN/LPS-induced liver damage, we injected the antioxidant NAC. NAC-treated mice showed a significant reduction in GalN/LPSinduced liver injury (fig. 3c). Thus, hypothermia reduces GalN/LPS-induced hepatocyte death through mechanisms that may depend on attenuated ROS accumulation. 


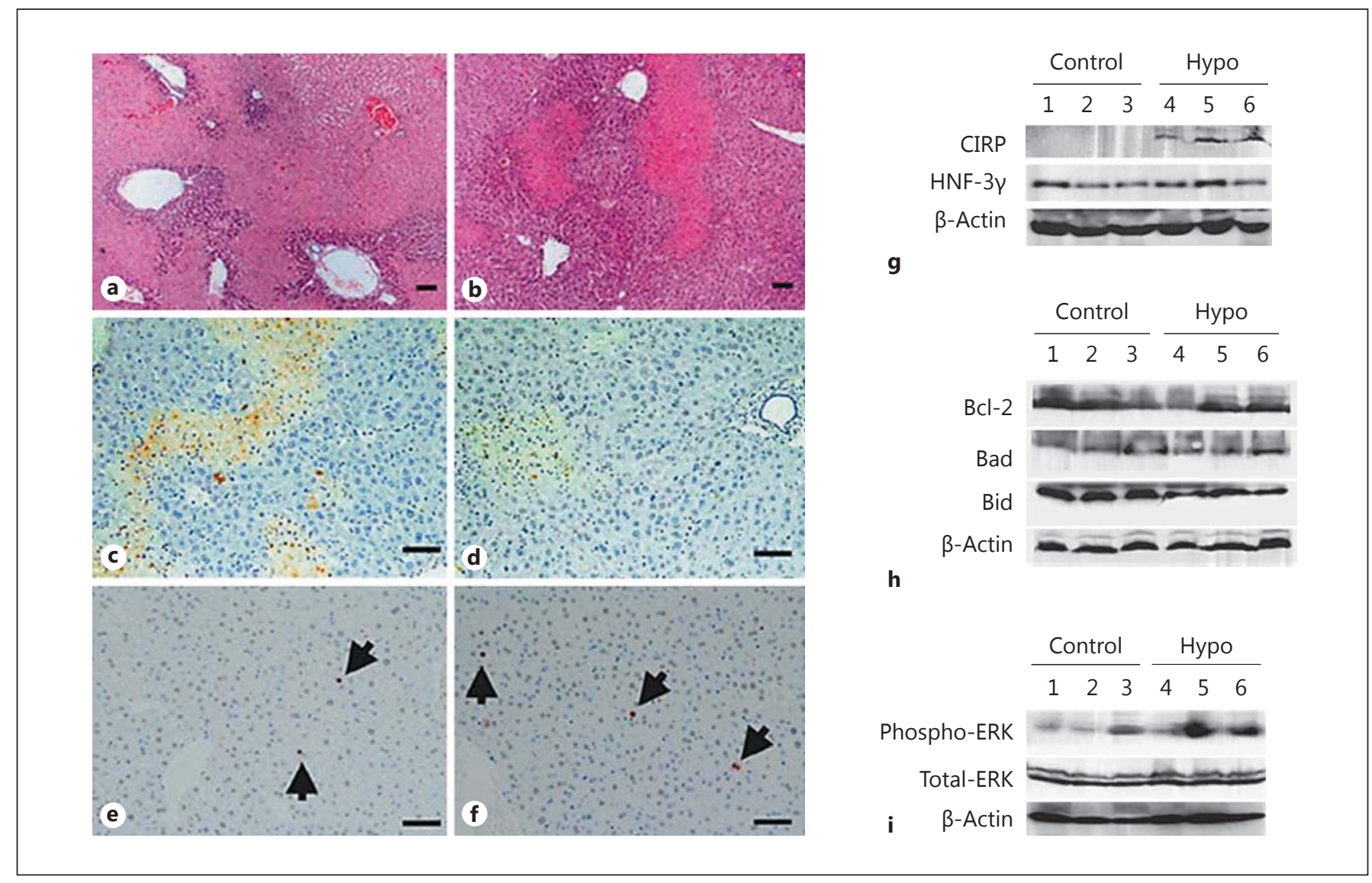

Fig. 5. Hypothermia upregulates CIRP in con A-induced hepatitis. a-f Liver histology. Mice were injected with $25 \mathrm{mg} / \mathrm{kg}$ body weight of con A. One hour later, the ambient temperature was changed to $25^{\circ} \mathrm{C}(\mathbf{a}, \mathbf{c}, \mathbf{e})$ or $6^{\circ} \mathrm{C}(\mathbf{b}, \mathbf{d}, \mathbf{f})$ for $1.5 \mathrm{~h}$, and then returned to room temperature. Twenty-four hours after the injection, the mice were euthanised and liver sections were obtained after fixation. Haematoxylin and eosin staining (a, b); TUNEL staining (c, d); immunohistochemical staining with mouse anti-PCNA antibody and horseradish peroxidase-conjugated anti-mouse antibody (e, f). Arrows indicate PCNA-positive cells. Scale bar $=50 \mu \mathrm{m}$. g-i Gene expression. Groups of mice were treated as above, and the expression of CIRP and HNF-3 $\gamma$ (g), Bcl-2 family members (h) and ERK (i) in the livers of control mice and hypothermic mice (Hypo) was analysed by Western blotting using the indicated antibodies. Results with representative samples are shown.

\section{Hypothermia Upregulates CIRP Expression and Improves the Survival Rate in con A-Induced Hepatitis}

TNF- $\alpha$ has been suggested to be a crucial factor in fulminant hepatitis [8]. In con A-induced hepatitis, a mouse model of fulminant hepatitis, the intrahepatic levels of cytokines, including TNF- $\alpha$, maximally increase $1 \mathrm{~h}$ after con A administration [15]. As shown in figure 4, hypothermic treatment improved the survival rate, but the improvement was not significant $(\mathrm{p}=0.096)$.

Histological examinations revealed that con $\mathrm{A}$ induced severe morphological changes in the liver (fig. 5a). Dilatation of veins and bile ducts was prominent. Massive de- generative lesions consisting of dead parenchymal cells were observed in the midlobular area. The liver of mice in the hypothermia group showed smaller areas of the lesion than the liver of the mice in the control group (fig. 5b). Cells positive for TUNEL staining were localized in the parenchymal cells in the midlobular area and adjacent to the degenerative lesions, and the areas with TUNEL-positive cells were smaller in the hypothermia group (fig. 5c, d). Cold exposure slightly reduced the number of PCNA-positive cells in mice without con A challenge (4.5 \pm 1.2 vs. $3.4 \pm 0.8$ per 1,000 cells). As shown in figure $5 \mathrm{e}$ and $\mathrm{f}, \mathrm{PCNA}$ immunoreactivity was decreased after con A administration in the control and hypothermia groups 
to equivalent levels ( $1.4 \pm 0.5$ vs. $1.8 \pm 0.6$ per 1,000 cells). These results suggest that in con A-induced hepatitis, hypothermia improves the survival of mice not by enhancing hepatocyte regeneration but rather by suppressing apoptosis.

The stress response protein CIRP protects cells by activating the ERK pathway [7]. HNF-3 $\gamma$ shows a hepatoprotective effect in acute liver injury [16]. Hypothermia induced the expression of CIRP, but not HNF- $3 \gamma$, in the livers of con A-treated mice (fig. 5g). As shown in figure $5 \mathrm{~h}, \mathrm{Bid}$ was downregulated in livers in the hypothermia group. There was no difference in the protein levels of XIAP/ILP and other Bcl-2 family members, including Bcl-2, Bcl-xL, Bad and Mcl-1 (fig. 5h and data not shown). The level of phosphorylated ERK was increased in 2 out of 3 examined mice in the hypothermia group (fig. 5i).

\section{Discussion}

Fulminant hepatitis is a devastating liver disease with a progressive course and a high mortality rate [17]. Although several studies have shown that mild hypothermia has a protective effect against the encephalopathy resulting from severe liver injury [18], the direct effect of hypothermia on the liver has not been determined. In the present study, we found that hypothermia inhibited apoptosis in the liver and increased the survival rate in mice with con A-induced hepatitis and GalN/LPS-induced hepatitis, which are considered to be relevant to human fulminant hepatitis [19]. Apoptosis is essential for the homeostasis of organs such as the liver [20]. In both human fulminant hepatitis and its animal models, apoptosis of hepatocytes is mediated by death receptors such as Fas (CD95) and the TNF- $\alpha$ receptor [20, 21]. In the death receptor pathway, the pro-apoptotic protein Bid is processed, and its translocation to the mitochondria activates the mitochondrial apoptotic pathway [22]. $\mathrm{Bid}$ is required, at least in some cells, for death receptor activation to initiate the apoptosis cascade. Here, we showed that in the livers of mice treated with con $\mathrm{A}$, the Bid protein level was lower in the hypothermia group than in the control group (fig. 5). These results suggest that the protective effect of hypothermia in mice is mediated, at least partly, by the decrease in the Bid protein level in the liver. CIRP blunts TNF- $\alpha$-mediated apoptosis via ERK activation [7] and inhibits $\mathrm{H}_{2} \mathrm{O}_{2}$-induced apoptosis through upregulation of thioredoxin expression [23]. CIRP, which was upregulated by hypothermia in this study, may contribute to the anti-apoptotic effects of hypothermia by regulating ERK activity and ROS accumulation in the liver.

Several mechanisms have been proposed to explain the increased resistance of humans and animals to tissue damage as body temperature is reduced. Hypothermia suppresses the production of superoxide anions, nitric oxide and TNF- $\alpha$ in ischemic cells [24]. The hepatic inflammatory response after ischemia is suppressed by hypothermia through selective inhibition of JNK and activator protein-1 [25]. ROS promote TNF- $\alpha$-induced death and sustained JNK activation by inhibiting MAP kinase phosphatases $[11,26]$. Akt activation increases intracellular ROS levels through increased oxygen consumption and by inhibition of the expression of ROS scavengers downstream of FoxO, particularly sestrin 3 [10]. In the present study, we demonstrated that hypothermia suppressed liver injury and the Akt and JNK pathways in the livers of GalN/LPS-treated mice (fig. 3). Furthermore, mice treated with an antioxidant showed a significant reduction in the severity of liver injury. These data suggest that the attenuation of ROS accumulation is involved in the cyto-protective effect of hypothermia. Further elucidation of the underlying mechanisms of these protective effects will lead to the future development of novel therapeutic modalities.

\section{Acknowledgements}

We thank A.M. Park and H. Munakata for technical assistance and discussions. This work was partly supported by Grants-in-Aid from the Ministry of Education, Culture, Sports, Science and Technology of Japan, the Japan Society for the Promotion of Science, Takeda Science Foundation and the Smoking Research Foundation of Japan.

\section{Disclosure Statement}

The authors have no conflicts of interest to disclose.

References

1 Curfman GD: Hypothermia to protect the brain. N Engl J Med 2002;346:546.

2 Darby JM: Therapeutic hypothermia after cardiac arrest. N Engl J Med 2002;347:63-65.

- 3 Wu TC, Grotta JC: Hypothermia for acute ischaemic stroke. Lancet Neurol 2013;12: 275-284.

4 Hong MF, Dorian P: Update on advanced life support and resuscitation techniques. Curr Opin Cardiol 2005;20:1-6. 
5 Diestel A, Roessler J, Berger F, Schmitt KR: Hypothermia downregulates inflammation but enhances IL- 6 secretion by stimulated endothelial cells. Cryobiology 2008;57:216-222.

6 Sakurai T, Itoh K, Liu Y, Higashitsuji H, Sumitomo Y, Sakamaki K, Fujita J: Low temperature protects mammalian cells from apoptosis initiated by various stimuli in vitro. Exp Cell Res 2005;309:264-272.

-7 Sakurai T, Itoh K, Higashitsuji H, Nonoguchi K, Liu Y, Watanabe H, Nakano T, Fukumoto M, Chiba T, Fujita J: Cirp protects against tumor necrosis factor- $\alpha$-induced apoptosis via activation of extracellular signal-regulated kinase. Biochim Biophys Acta 2006;1763:290-295.

$\checkmark 8$ Bradham CA, Plumpe J, Manns MP, Brenner DA, Trautwein C: Mechanisms of hepatic toxicity. I. TNF-induced liver injury. Am J Physiol 1998;275:G387-G392.

9 Sakurai T, Kudo M, Umemura A, He G, Elsharkawy AM, Seki E, Karin M: p38a inhibits liver fibrogenesis and consequent hepatocarcinogenesis by curtailing accumulation of reactive oxygen species. Cancer Res 2013;73: 215-224.

10 Nogueira V, Park Y, Chen CC, Xu PZ, Chen ML, Tonic I, Unterman T, Hay N: Akt determines replicative senescence and oxidative or oncogenic premature senescence and sensitizes cells to oxidative apoptosis. Cancer Cell 2008; 14:458-470.

11 Sakurai T, He G, Matsuzawa A, Yu GY, Maeda S, Hardiman G, Karin M: Hepatocyte necrosis induced by oxidative stress and IL-1a release mediate carcinogen-induced compensatory proliferation and liver tumorigenesis. Cancer Cell 2008;14:156-165.
12 Mine H, Sakurai T, Kashida H, Matsui S, Nishida N, Nagai T, Hagiwara S, Watanabe T, Kudo M: Association of Gankyrin and stemness factor expression in human colorectal cancer. Dig Dis Sci 2013;58:2337-2344.

13 Masuda T, Itoh K, Higashitsuji H, Higashitsuji H, Nakazawa N, Sakurai T, Liu Y, Tokuchi H, Fujita T, Zhao Y, Nishiyama H, Tanaka T, Fukumoto M, Ikawa M, Okabe M, Fujita J: Cold-inducible RNA-binding protein (Cirp) interacts with Dyrk1b/Mirk and promotes proliferation of immature male germ cells in mice. Proc Natl Acad Sci USA 2012;109: 10885-10890.

14 Guyton AC: Textbook of Medica Physiology, ed 7. Philadelphia, Saunders, 1986.

15 Sass G, Heinlein S, Agli A, Bang R, Schumann J, Tiegs G: Cytokine expression in three mouse models of experimental hepatitis. $\mathrm{Cy}$ tokine 2002;19:115-120.

16 Nakamura T, Akiyoshi H, Shiota G, Isono M, Nakamura K, Moriyama M, Sato K: Hepatoprotective action of adenovirus-transferred HNF- $3 \gamma$ gene in acute liver injury caused by $\mathrm{CCl}_{4}$. FEBS Lett 1999;459:1-4.

17 Galun E, Axelrod JH: The role of cytokines in liver failure and regeneration: potential new molecular therapies. Biochim Biophys Acta 2002;1592:345-358.

18 Jalan R: Intracranial hypertension in acute liver failure: pathophysiological basis of rational management. Semin Liver Dis 2003;23: 271-282.
9 Tiegs G, Hentschel J, Wendel A: A T cell-dependent experimental liver injury in mice inducible by concanavalin A. J Clin Invest 1992; 90:196-203.

-20 Galle PR, Hofmann WJ, Walczak H, Schaller H, Otto G, Stremmel W, Krammer PH, Runkel L: Involvement of the CD95 (APO-1/Fas) receptor and ligand in liver damage. J Exp Med 1995;182:1223-1230.

21 Hengartner MO: The biochemistry of apoptosis. Nature 2000;407:770-776.

22 Luo X, Budihardjo I, Zou H, Slaughter C, Wang X: Bid, a Bcl2 interacting protein, mediates cytochrome $\mathrm{c}$ release from mitochondria in response to activation of cell surface death receptors. Cell 1998;94:481-490.

23 Li S, Zhang Z, Xue J, Liu A, Zhang H: Coldinducible RNA binding protein inhibits $\mathrm{H}_{2} \mathrm{O}_{2}$-induced apoptosis in rat cortical neurons. Brain Res 2012;1441:47-52.

24 Kataoka K, Yanase H: Mild hypothermia - a revived countermeasure against ischemic neuronal damages. Neurosci Res 1998;32: 103-117.

25 Kato A, Singh S, Mcleish KR, Edwards MJ, Lentsch AB: Mechanisms of hypothermic protection against ischemic liver injury in mice. Am J Physiol Gastrointest Liver Physiol 2002;282:G608-G616.

26 Kamata H, Honda S, Maeda S, Chang L, Hirata $\mathrm{H}$, Karin M: Reactive oxygen species promote TNFa-induced death and sustained JNK activation by inhibiting MAP kinase phosphatases. Cell 2005;120:649-661. 